\title{
CFD analysis of a one-pass photovoltaic/thermal air system with and without offset strip fins
}

\author{
Moustafa Al-Damook ${ }^{1,2^{*}}$, Darron Dixon-Hardy ${ }^{3}$, Peter J. Heggs ${ }^{3}$, Mansour Al Qubeissi ${ }^{4}$, Khaled Al-Ghaithi ${ }^{5}$, \\ Patrick E. Mason ${ }^{3}$, and Joshua Cottom ${ }^{3}$ \\ ${ }^{1}$ School of Mechanical Engineering, University of Leeds, LS2 9JT, Leeds, United Kingdom \\ ${ }^{2}$ Renewable Energy Research Centre, University of Al-Anbar, Iraq \\ ${ }^{3}$ School of Chemical and Process Engineering, University of Leeds, Leeds, United Kingdom \\ ${ }^{4}$ Faculty of Engineering, Environment and Computing, Coventry University, Coventry, United Kingdom \\ ${ }^{5}$ School of computing, Faculty of Engineering, University of Leeds, Leeds LS2 9JT, United Kingdom
}

\begin{abstract}
The focus on managing PV panel temperature has undergone a remarkable development in the last two decades. Specifically, in countries with moderate weather temperature and high insolation, the problem of keeping the PV cell temperature in an optimal range has been managed by use of PV/T collectors. In this work, a single pass PV/T collector using laminar air flow has been assessed. Two PV/T collector designs are utilised, one with and one without offset strip fins. COMSOL Multiphysics v5.3a has been used for the analysis of the thermal and electrical performances. Two assumptions were implemented in order to reduce the computational time from 95 hours to 7 hours, namely ignoring radiative effects between the fins and the wall channels, and representing thin layers as 2D boundaries, whilst ensuring a high level of conformity (4\%), Monocrystalline silicon PV cells were used with a power temperature coefficient of $0.41 \%$. A validation against work in the literature was made, showing a good consistency. The objective of this work is to verify the performance of the air PV/T collector with offset strip fins compared to an unfinned air PV/T collector. The results reveal that the use of offset strip fins has a noticeable impact on both the electrical and thermal efficiencies of the system. In addition, the maximum combined efficiency $\left(\eta_{C o}\right)$ for the finned PV/T system is $84.7 \%$ while the unfinned PV/T system is $51.2 \%$.
\end{abstract}

\section{Introduction}

The capability of photovoltaic (PV) systems has been developed considerably in recent years to the point that some PVs can absorb more than $75 \%$ of the insolation energy and up to $18 \%$ of this being converted to electrical power [1]. The remainder of the absorbed energy is released as heat, causing the temperature of the PV cells to rise. Once the temperature increases above standard conditions $\left(25^{\circ} \mathrm{C}\right.$ and $\left.1000 \mathrm{~W} \mathrm{~m}^{-2}\right)$, the cell efficiency falls by approximately $0.4-0.65 \%$ per degree Celsius [1]. This reduction is defined by the temperature coefficient of the PV cell. For example, for a panel with a temperature coefficient of $-0.65 \%$, the panel's maximum power will reduce by $0.65 \%$ for every $1{ }^{\circ} \mathrm{C}$ rise. It is therefore important to implement a means of controlling the temperature rise (i.e. cooling) to keep the panel operating at optimal conditions. If the heat removed from the panel can be usefully exploited, then this provides an additional advantage and the system can be classed as a photovoltaic/thermal system (PV/T). Ideally, PV/T technology should allow the PV cell to operate in a temperature range optimised for electrical efficiency, as well as producing useable heat. The efficiencies of both the PV system and the thermal system can be considered as an overall (hybrid) efficiency.

A number of studies have investigated the effects of extended surfaces on improving PV/T system hybrid efficiency. Extended surfaces can be classed as three main types: traditional fins [2, 3]; interposition of a thin metallic sheet (TMS) [4-8] and obstacles (ribs) [4, 5, 9, $10]$.

To ensure lower-pressure drop and higher contact area [11-14], a traditional offset strip fin is employed.

The present study numerically examines the use of an offset strip fin design, the performance of which is evaluated by comparison with a bare solar collector design (without fins). An analysis of this kind for a PV/T system with offset fins has not previously been explored.

\section{Numerical investigations}

Figure 1 (a) illustrates the various layers comprising the PV module and (b) is a schematic view of a single pass $\mathrm{PV} / \mathrm{T}$ collector without fins. Figure 2 (a) is a 3D view of the offset longitudinal fins arrangement to be attached to the bottom of the PV module and (b) provides the dimensions of these fins. The physical dimensions of the

\footnotetext{
* Corresponding author: mnmaab@leeds.ac.uk
} 
$\mathrm{PV} / \mathrm{T}$ collectors are listed in Table 1 . The thicknesses and physical properties of the layers in the PV module are detailed in Table 2. Mathematical models of these two collector systems are investigated numerically using COMSOL Multiphysics v5.3a. The model of the one pass air PV/T collector consists of three parts: the PV thermal and electrical absorber plate, the channel ducting, and the back insulation. The second model is similar, but includes the longitudinal offset strip fins attached to the base of the PV module.

Table 1. Specification of PV/T Collectors.

\begin{tabular}{lc}
\hline Collector length $(\mathrm{L})(\mathrm{mm})$ & 660 \\
\hline Collector width $(\mathrm{W})(\mathrm{mm})$ & 340 \\
\hline Symmetry width $(\mathrm{W})(\mathrm{mm})$ & 170 \\
\hline Duct depth $\left(\delta_{\mathrm{D} 1}\right)(\mathrm{mm})$ & 25 \\
\hline Bottom absorber plate thickness $(\mathrm{mm})$ & 1 \\
\hline Absorber plate thickness $(\mathrm{mm})$ & 0.5 \\
\hline Fin thickness $(\mathrm{mm})$ & 0.5 \\
\hline Length of fin $\left(\mathrm{L}_{\mathrm{f}}\right)(\mathrm{mm})$ & 50 \\
\hline Space of fin $\left(\mathrm{S}_{\mathrm{f}}\right)(\mathrm{mm})$ & 20 \\
\hline
\end{tabular}

Table 2. Physical properties of the PV module layers BP 585 $[15,16]$.

\begin{tabular}{l|lllll}
\hline Layer & $\mathrm{t}$ & $\mathrm{k}$ & $\mathrm{r}$ & $\mathrm{cp}$ & $\mathrm{e}$ \\
\hline PV Glass & 3 & 1.8 & 3000 & 500 & 0.84 \\
EVA & 0.5 & 0.35 & 960 & 2090 & - \\
PV cells & 0.3 & 148 & 2330 & 677 & 0.7 \\
Tedlar & 0.5 & 0.2 & 1200 & 1250 & 0.87
\end{tabular}

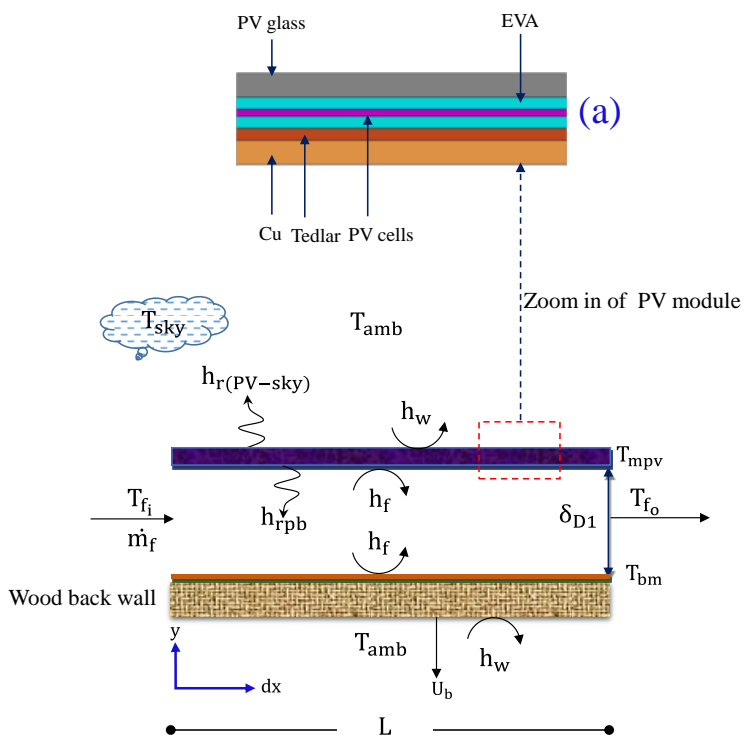

(b)

Fig. 1. (a) The thermal schematic of air PV/T collector, and (b) the PV module layers. (a)

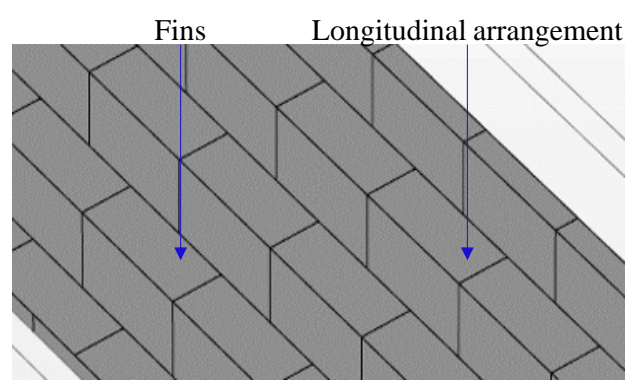

(b)

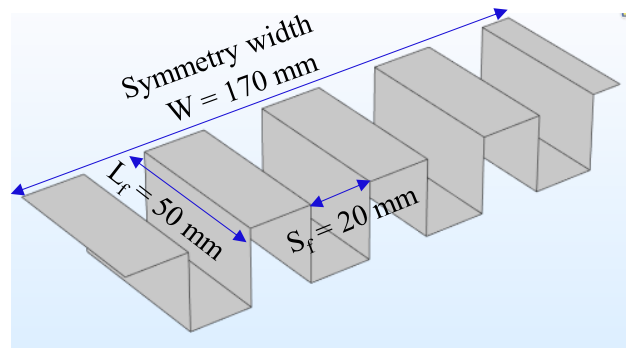

Fig. 2. Offset strip fins longitudinal arrangement: (a) the 3D view of fins array arranged longitudinally and (b) 3D view of one array with fin dimensions.

To simulate realistic and accurate results, a surface-tosurface radiation module was used with an 'External Radiation' node to simulate the incident solar radiation instead of using constant heat flux as illustrated in Eq.(1). Eq.(2) represents the governing equation for modelling the emission and absorption between interfacing surfaces with temperature $\mathrm{T}$ into air flow or to the surroundings.

$$
q_{r}=\varepsilon\left(G-E_{b}\right)=\varepsilon\left(T_{s}^{4}-T^{4}\right)
$$

where $\varepsilon$ is the surface emissivity, $G$ is incident solar radiation $\left(\mathrm{W} \mathrm{m}^{-2}\right)$, and $E_{b}$ is the blackbody hemispherical total emissive power, estimated as:

$$
E_{b}=\sigma A_{a} T^{4}
$$

In order to avoid the complexity, the emissivity of PV layers and glass set as constant (independent wavelength and temperature) since the glass is ultra-clear. All thermal properties of the materials coolant (air) are set as temperature dependent.

Eq.(3) is the general governing equation for the $3 \mathrm{D}$ conjugate heat transfer system under transient conditions. Assuming steady state conditions, electrical power generation $\left(\dot{Q}_{v}\right)$ and a stationary PV panel, Eq.(3) reduces to Eq.(4). The boundary conditions were set as presented in Table 3.

Table 3. Boundary conditions.

\begin{tabular}{lc}
\hline Lower wind velocity $\left(\mathrm{m} \mathrm{s}^{-1}\right)$ & 0.5 \\
\hline Upper wind velocity $\left(\mathrm{m} \mathrm{s}^{-1}\right)$ & 3 \\
\hline Incident solar radiation $\left(\mathrm{Wm}^{-2}\right)$ & 1000 \\
\hline Ambient temperature ${ }^{\circ} \mathrm{C}$ & 50 \\
\hline $\operatorname{Re}$ & $400-2200$ \\
\hline Outlet pressure $\left(\mathrm{Nm}^{-2}\right)$ & 0 \\
\hline Inlet air temperature ${ }^{\circ} \mathrm{C}$ & 50 \\
\hline $\begin{array}{l}\text { No slip condition at fins and wall collector } \\
\left(\mathrm{m} \mathrm{s}^{-1}\right)\end{array}$ & $\mathrm{U}_{\mathrm{x}, \mathrm{y}, \mathrm{z}}=0$ \\
\hline
\end{tabular}




$$
\begin{gathered}
\frac{D\left(\rho C_{p} T\right)}{D t}=\nabla \cdot(k \nabla T)+\dot{Q}_{v} \\
\nabla \cdot(k \nabla T)+\dot{Q}_{v}=0
\end{gathered}
$$

The extracted power of the PV module generation can be estimated by Eq.(5) $[15,17]$.

$$
\begin{gathered}
P_{\text {module }}=I_{m} V_{m}=F F I_{s c} V_{o c} \\
=\eta_{\text {cell }} A_{\text {cells }} G \alpha_{p v} \\
\eta_{\text {cell }}=\eta_{\text {ref }}\left(1-\beta_{\text {ref }}\left(T_{\text {mpv }}-T_{\text {ref }}\right)\right)
\end{gathered}
$$

where $\eta_{\text {cell }}$ is the electrical efficiency of PV cell.

The thermal performance can be estimated as [18]:

$$
\eta_{t h}=\dot{Q}_{u} / \dot{Q}_{s}
$$

where $\dot{\mathrm{Q}}_{\mathrm{u}}$ is the effective heat extraction by PV/T system:

$$
\dot{Q}_{u}=\dot{M} C p\left(T_{o}-T_{i}\right)
$$

where $\dot{M}$ is mass flow rate $\left(\mathrm{kg} \mathrm{s}^{-1}\right)$. The overall heat produced by incident solar radiation is given by:

$$
\dot{Q}_{s}=G A_{a}
$$

The total collector efficiency (hybrid efficiency) of the $\mathrm{PV} / \mathrm{T}$ collector can be estimated using $\operatorname{Eq}(10)[19,20]$.

$$
\eta_{c o}=\eta_{t h}+\frac{\eta_{e l e}}{C_{f}}
$$

where $C_{f}$ is the conversion factor of the thermal power plant and lies between 0.29 to 0.4 [19], and is assumed to be 0.36 in our analysis.

Three further assumptions were implemented to reduce the computational time. The first one was ignoring radiative effects between the fins and the wall channels while the second was representing thin layers as $2 \mathrm{D}$ boundaries and the last is a symmetry boundary condition in Y flow direction plan. The computational time reduced therefore from 95 hours using a high performance computer (HPC) to 7 hours using a desktop PC.

\section{Results and discussion}

Numerical investigations were performed using COMSOL Multiphysics v5.3a to assess the influence of the PV panel temperature on the monocrystalline PV. Two approaches were used to ensure the accuracy of results; mesh independence tests and validation against previous literature work.

Table 4. The validation between CFD Model and [21].

\begin{tabular}{ccc}
\hline PV/T layers & {$[21]\left({ }^{\circ} \mathrm{C}\right)$} & CFD $\left({ }^{\circ} \mathrm{C}\right)$ \\
\hline $\mathrm{T}_{\mathrm{g}}$ & 30.5 & 32.3 \\
\hline $\mathrm{T}_{\mathrm{mpv}}$ & 31.3 & 32.0 \\
\hline $\mathrm{T}_{\mathrm{Tedlar}}$ & 28.8 & 31.7 \\
\hline $\mathrm{T}_{\mathrm{fm}}$ & 18.4 & 19.1 \\
\hline $\mathrm{T}_{\mathrm{fo}}$ & 20.5 & 20.3 \\
\hline $\mathrm{T}_{\mathrm{ins}}$ & 19.7 & 16.1 \\
\hline
\end{tabular}

The validation with [21] showed good agreement as shown in Table 4.The mesh independence test was performed to enhance the convergence speed and ensure high mesh quality. The number of elements was increased until the solution remained constant, as presented in Table 5. Both thermal efficiency $\eta_{t h}$ and pressure drop $\Delta p(\mathrm{~Pa})$ were studied in this test.

Table 5. Mesh independent test analysis.

\begin{tabular}{cccc}
\hline Element size & $\begin{array}{c}\text { No of } \\
\text { elements }\end{array}$ & $\eta_{\text {th }}$ & $\Delta \mathrm{p}(\mathrm{Pa})$ \\
\hline Very coarse & 114096 & 65.0 & 13.3 \\
\hline less coarse & 241591 & 62.8 & 8.3 \\
\hline Coarse & 427075 & 60.8 & 5.5 \\
\hline Fine & 1201596 & 57.8 & 3.3 \\
\hline Very Fine & 2097077 & 57.0 & 2.8 \\
\hline
\end{tabular}

Figure 3 shows the impact of the PV panel temperature on the PV electrical efficiency for both with and without fins systems for a range of Reynolds numbers (400-2200). The temperature of the PV panel is seen to be inversely proportional to Reynolds number. This is expected because of the convective heat transfer coefficient is directly proportional to the Reynolds number. This decrease in temperature results in a corresponding increase in electrical efficiency as expected by Eq.(6). More importantly at Reynolds numbers between 4001000 , the temperature of unfinned is lower than that of the finned system. As a result, the unfinned system had a better electrical efficiency in that range. However, for Reynolds numbers more than 1000 , the temperature of the finned system was markedly lower than that of the unfinned model. This, as can be seen from Figure 3, made the finned system more electrically efficient in this range. This effect is owing to the fin effectiveness at Reynold numbers less than 1000 working as a conductive resistance layer to heat transfer rather than a dissipater of heat. In other words, the ratio of heat transfer rate of the finned PV/T model was lower, compared to the unfinned model at Reynolds number less 1000 under the aforementioned conditions.

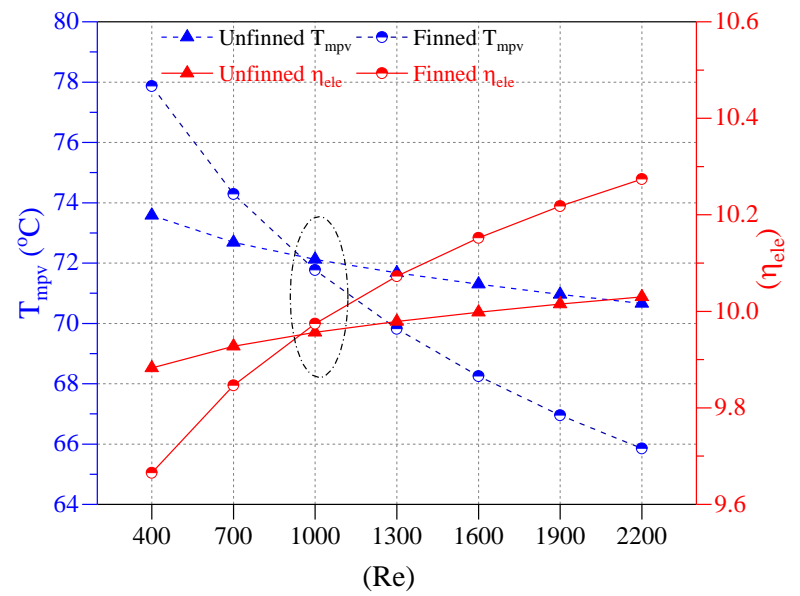

Fig. 3. Effect of PV panel temperature rise on the electrical efficiency under different Reynolds number ranges for finned and unfinned air PV/T collectors. 


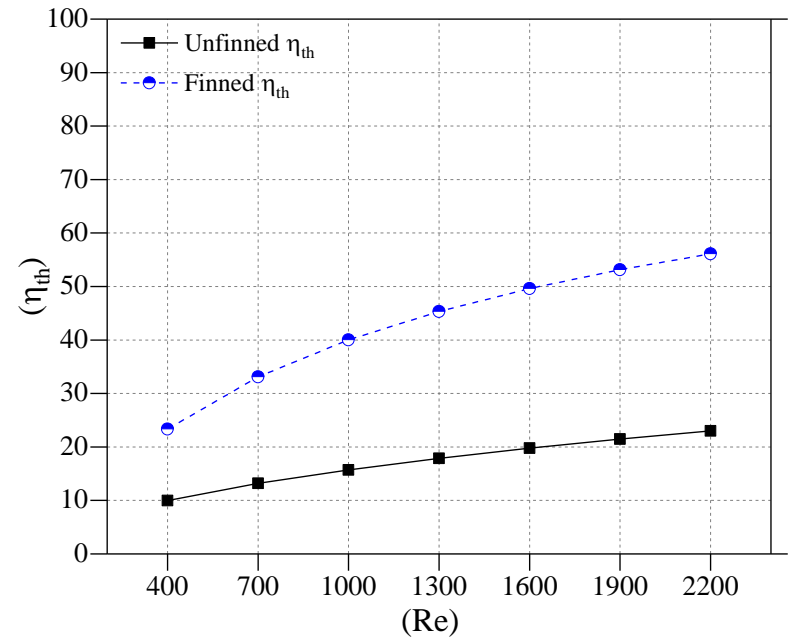

Fig. 4. Effect of Reynolds number on the thermal efficiency for finned and unfinned air PV/T collectors.

The system thermal efficiency enhancements for finned and unfinned air PV/T were calculated using Eq.(7). In Figure 4, a comparison is shown for the thermal efficiencies of the two models with Reynolds number range between 400-2200. The results obtained from this figure revealed that maximum and minimum percentage improvements in thermal efficiency were $143.7 \%$ and $134.1 \%$, respectively.

In addition, Figure 5 illustrates this finding for the total system efficiency using Eq.(10), with maximum and minimum percentage enhancements of $66.36 \%$ and $34.12 \%$, respectively. The maximum combined efficiency for the finned system was $84.7 \%$ in comparison to a maximum of $51.2 \%$ for the unfinned system.

This enhancement, however, increased the pressure drop penalty in the system, thus, requiring more pumping power calculated at 2 to 6 times compared with the unfinned PV/T system (see Figure 6).

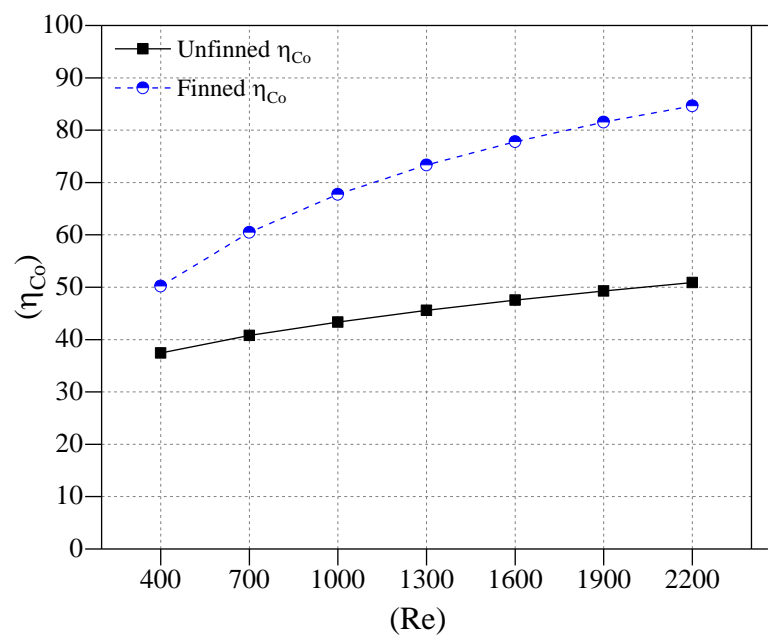

Fig. 5. Effect of Reynolds number on the combined efficiency for finned and unfinned air PV/T collectors.

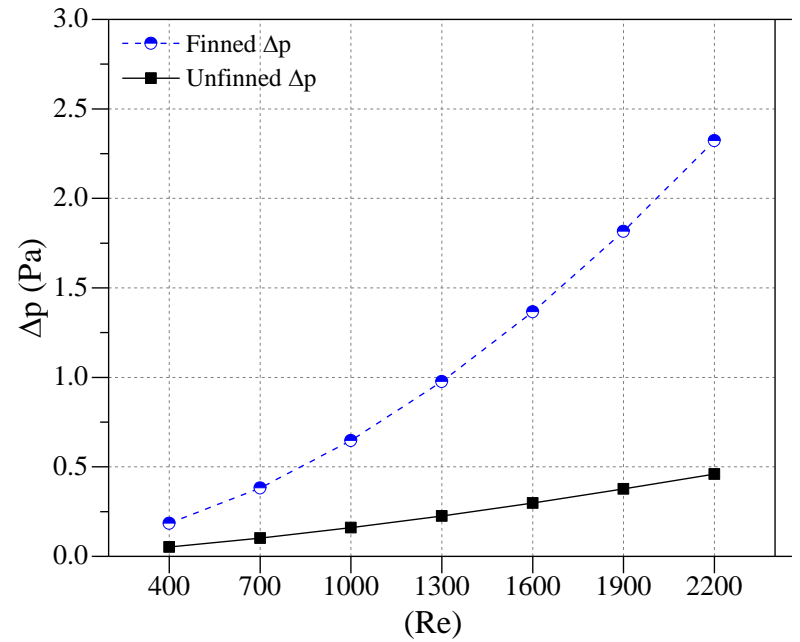

Fig. 6. Effect of Reynolds number on the pressure drop for finned and unfinned air PV/T collectors.

Figure 7 (a) and (b) presents the velocity distribution for the finned model. In (a), the velocity distribution is for a longitudinal YX cut-plane viewpoint at $12.5 \mathrm{~mm}$ height above the bottom absorber plate ( $\mathrm{Y}$ is the dimension in air flow direction, $\mathrm{X}$ is the dimension in collector width and $\mathrm{Z}$ is the dimension in air depth direction). In (b), the velocity distribution is for several ZX cut-plane viewpoints. The velocity profiles between fins can be seen to have a parabolic profile with 0 velocity at the wall as expected due to the nonslip condition. The entrance length can also be noticed near the inlet as expected after which a developed flow was established.

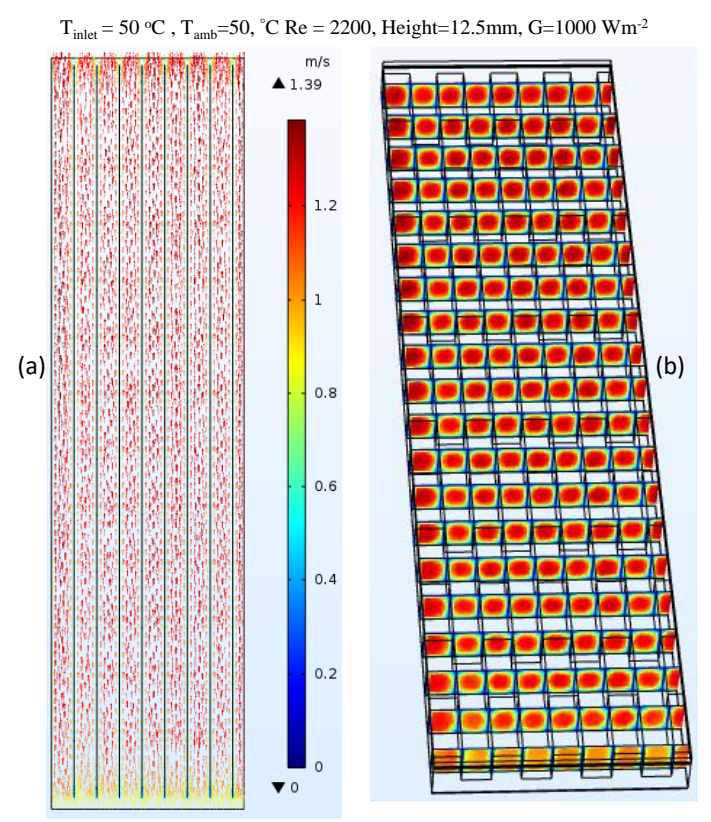

Fig. 7. The velocity profile for a finned air PV/T model, showing (a) XY cut-plane and (b) XZ cut-plane viewpoints.

\section{Conclusions}

Two air PV/T collectors have been developed using COMSOL Multiphysics v5.3a, namely, a single pass PV/T collector without fins, and a single pass $\mathrm{PV} / \mathrm{T}$ collector 
including a longitudinal fin arrangement. The weather conditions employed considered the worst case scenario of $1000 \mathrm{~W} \mathrm{~m}^{-2}$ and $50{ }^{\circ} \mathrm{C}$. For this particular model, the fundamental results revealed that the use of offset strip fins enhanced the thermal efficiency of the PV/T collector and maintained the electrical PV efficiency at an acceptable level. The maximum combined efficiency obtained was $84.7 \%$, which was very acceptable for an air PV/T collector. Future work will focus on utilising different duct and offset arrangements.

\section{Acknowledgments}

The first author is extremely grateful to the Higher Committee for Education Development (HCED), Iraq, and the Renewable Energy Research Centre, University of Anbar, for the their support to the project.

\section{Nomenclature}

\begin{tabular}{|c|c|}
\hline PV & Photovoltaic \\
\hline $\mathrm{PV} / \mathrm{T}$ & Photovoltaic/thermal \\
\hline $\mathrm{t}$ & Thickness (mm) \\
\hline$k$ & Thermal conductivity $\left(\mathrm{W} \mathrm{m}^{-1} \mathrm{~K}^{-1}\right)$ \\
\hline $\mathrm{h}$ & Heat transfer coefficient $\left(\mathrm{W} \mathrm{m}^{-2} \mathrm{~K}^{-1}\right)$ \\
\hline$C p$ & Specific heat capacity of air $\left(\mathrm{J} \mathrm{kg}^{-1} \mathrm{~K}^{-1}\right)$ \\
\hline$T$ & Temperature ${ }^{\circ} \mathrm{C}$ \\
\hline CFD & Computational Fluid Dynamics \\
\hline$A$ & Area $\left(\mathrm{m}^{2}\right)$ \\
\hline$P$ & Power (W) \\
\hline$u$ & Velocity vector in $\mathrm{x}$ direction $\left(\mathrm{m} \mathrm{s}^{-1}\right)$ \\
\hline$v$ & Velocity vector in y direction $\left(\mathrm{m} \mathrm{s}^{-1}\right)$ \\
\hline$w$ & Velocity vector in $\mathrm{z}$ direction $\left(\mathrm{m} \mathrm{s}^{-1}\right)$ \\
\hline$\dot{Q}$ & Heat rate $(\mathrm{W})$ \\
\hline$G$ & Incident solar radiation $\left(\mathrm{W} \mathrm{m}^{-2}\right)$ \\
\hline$I$ & Current (A) \\
\hline$V$ & Voltage (V) \\
\hline$C_{f}$ & Conversion factor of the thermal power plant \\
\hline$F F$ & Fill factor \\
\hline \multicolumn{2}{|c|}{ Greek Symbols } \\
\hline$\rho$ & Density $\left(\mathrm{kg} \mathrm{m}^{-3}\right)$ \\
\hline$\beta$ & Power temperature coefficient \\
\hline$\varepsilon$ & Emissivity \\
\hline$\eta$ & Efficiency \\
\hline$\alpha$ & Absorptivity \\
\hline$\sigma$ & $\begin{array}{l}\text { Stefan-Boltzmann constant } 5.67 \times 10^{-8} \\
\left(\mathrm{~W} \mathrm{~m}^{-2} \mathrm{~K}^{-4}\right)\end{array}$ \\
\hline \multicolumn{2}{|c|}{ Subscripts } \\
\hline $\mathrm{W}$ & Wind \\
\hline $\mathrm{amb}$ & Ambient weather conditions \\
\hline $\mathrm{s}$ & Sky and solar or surrounding \\
\hline $\mathrm{r}$ & Radiation \\
\hline $\mathrm{mpv}$ & Average PV module temperature \\
\hline $\mathrm{f}$ & Fluid \\
\hline $\mathrm{rpb}$ & Radiation between lower and upper absorbers \\
\hline o & Out \\
\hline $\mathrm{i}$ & Inlet \\
\hline A & Aperture \\
\hline $\mathrm{g}$ & Glass \\
\hline $\mathrm{fm}$ & Mean fluid \\
\hline th & Thermal \\
\hline
\end{tabular}

$\begin{array}{ll}\text { Co } & \text { Combined } \\ \text { ele } & \text { Electrical } \\ \text { ins } & \text { Insulation } \\ \text { bm } & \text { Bottom Absorber Plate } \\ \text { v } & \text { Volume } \\ \text { m } & \text { Maximum power point } \\ \text { oc } & \text { Open circuit voltage } \\ \text { sc } & \text { Short circuit current } \\ \text { ref } & \text { Reference }\end{array}$

\section{References}

1. A. Makki, S. Omer, H. Sabir, Renewable and sustainable energy reviews, 41, p. 658-684 (2015)

2. M. Tabatabaian, W. Tivy, C. Bibby, Americ. Soci. of Mech. Engin. (2012)

3. R. Kumar, M.A. Rosen, Applied Energy, 88, 11, 36033614 (2011)

4. D. Gupta, S. Solanki, J. Saini, Solar Energy, 51, 1, p. 31-37 (1993)

5. Y. Tripanagnostopoulos, Solar energy, 81, 9, p. 11171131 (2007)

6. J. Tonui and Y. Tripanagnostopoulos, Renewable energy, 32, 4, p. 623-637 (2007)

7. J. Tonui, Y. Tripanagnostopoulos, Solar energy, 81, 4, p. 498-511 (2007)

8. J. Tonui, Y. Tripanagnostopoulos, Solar Energy, 82, 1, p. 1-12 (2008)

9. J. Zhu, M. Fiebig, N. Mitra, Int. Jour. of Heat and Mass Trans. 38, 3, p. 495-501 (1995)

10. J. Han, J.S. Park, Int. Jour. of Heat and Mass Trans., 31, 1, p. 183-195 (1988)

11. L.A. Tagliafico, F. Scarpa, M. De Rosa, Renewable and Sustainable Energy Reviews, 30, p. 526-537 (2014)

12. M. Yang, et al., Applied Energy, 113, p. 1349-1362 (2014)

13. S. Youcef-Ali S., J. Desmons, Renewable Energy, 31, 13, p. 2063-2075 (2006)

14. Handbook, A., ASHRAE handbook-fundamentals. (Atlanta, GA, 2009)

15. K. Kant et al., Solar Energy, 134, p. 147-155 (2016)

16. F. Calise, R.D. Figaj, L. Vanoli, Energies, 10, 4, p. 491 (2017)

17. S. Dubey, G. Sandhu, Tiwari, Applied Energy, 86, 5, p. 697-705 (2009)

18. K.E. Amori, M.A. Abd-AlRaheem, Renewable Energy, 63, p. 402-414 (2014)

19. F. Sarhaddi, et al., Applied Energy, 87, 7, p. 23282339 (2010)

20. N. Aste, C. del Pero, F. Leonforte, Solar Energy, 102, p. 98-115 (2014)

21. K.E. Amori, H.M.T. Al-Najjar, Applied Energy, 98, p. 384-395 (2012) 